\title{
WELCOME TO MIGRANTS IN A BORDERLESS EUROPE: BRYOPHYTES SHOW THE WAY TO GO
}

\author{
Alain Vanderpoorten*, Alice Ledent** \\ $\&$ Jairo Patiño***
}

\begin{abstract}
Reconstructing the Quaternary history of European bryophytes has long been challenging because, except for macro-remains preserved in peat, the fossil record is extremely poor as compared to vascular plants. Coalescent simulations revealed that the postglacial assembly of European bryophytes involves a complex history from multiple sources, contrasting with the prevailing model of northwards species migration from Mediterranean refugia. A scenario of extra-European postglacial recolonization clearly emerged as dominant. A bulk of the bryoflora that pre-existed in Europe before the Ice Age was reinforced by allochthonous migrants. The Atlantic European fringe was, in contrast, de novo colonized by species primarily distributed across tropical areas. We hypothesize that, for the particular case of the oceanic bryophyte floristic element, the Macaronesian islands represented a mandatory stepping-stone situated midway between the tropics and Europe due to the necessity for tropical species to pre-adapt under insular warm-temperate conditions before they successfully establish in temperate regions.
\end{abstract}

KEYWORDS: approximate bayesian computation, bryophytes, climate change, dispersal, historical biogeography, last glacial maximum, refugia.

\section{BIENVENIDA A LOS MIGRANTES EN UNA EUROPA SIN FRONTERAS: LOS BRIÓFITOS MUESTRAN EL CAMINO A SEGUIR}

\section{RESUMEN}

La reconstrucción de la historia cuaternaria de los briófitos europeos ha supuesto un reto durante mucho tiempo, ya que, a excepción de restos macroscópicos preservados en turberas, el registro fósil es excepcionalmente escaso en comparación con el de plantas vasculares. Análisis de coalescencia revelaron que el ensamblaje postglacial de las comunidades de briófitos europeos es compleja e incluye múltiples orígenes, contrastando con el modelo clásico que apunta al predominio de una migración hacia el norte desde refugios mediterráneos. Una parte significativa de la brioflora de Europa preexistente antes de la Edad del Hielo fue reforzada por migrantes alóctonos. Sin embargo, la Franja Atlántica europea fue principalmente colonizada por especies tropicales. Se postula que para el elemento florístico oceánico de briófitos, Macaronesia ha jugado un papel como 'stepping-stone' hacia Europa, un paso imprescindible para que especies tropicales puedan preadaptarse bajo los típicos regímenes climáticos suaves insulares, antes de establecerse en regiones templadas.

Palabras clave: computación bayesiana, briófitos, cambio climático, dispersión, biogeografía histórica, último máximo glacial, refugios. 


\section{INTRODUCTION}

The Quaternary period has been characterized by high amplitude climatic oscillations leading to glacial/interglacial cycles in both hemispheres, rapid sea-level changes (up to $140 \mathrm{~m}$ ), and megafaunal extinctions on all continents (Pillans and Gibbard 2012). The duration of each glacial/interglacial cycle varied through time. From the beginning of the Quaternary (i.e. 2.7 million years ago termed as $\mathrm{Ma}$ ) to $0.9 \mathrm{Ma}$, the duration of a cycle was $c .41$ thousand years (kyrs). It then expanded to a $c .100$ kyrs, which is the duration still observed now. Each cycle included a long glacial period and a short interglacial period. During the entire Quaternary period, there were around 40 to 50 glacial periods and the areas located beyond $65^{\circ}$ of latitude towards the poles were always covered in ice, while temperate areas right below those latitudes, were, more or less widely, covered in ice only during glacial periods (Berger et al., 2012). Although the Penultimate Last Glacial Maximum (c. 140 Kyrs ago, PLGM) (Schneider et al. 2013) involved globally larger ice-sheets, current species distributions were mostly shaped by the Last Glacial Maximum (LGM, c. 22 Kyrs ago) (Clark et al. 2009; Hewitt 2000). Indeed, the LGM was not only characterized by large ice-sheets, but also by a very dry climate around the globe, as evidenced, in Eurasia, by paleo-vegetation reconstructions based on pollen records describing this part of the world as mostly treeless, with a dominance of steppe, tundra and other xeric types of vegetations (Tzedakis et al. 2013; Wu et al. 2007).

Europe has long served as a model to study the impact of climate change on species distribution (Lumibao et al. 2017). The classical demographic scenario, the "southern refugium scenario" (Figure 1), is based on paleontological and phylogeographic evidence and suggests that species persisted in Mediterranean refugia during glacial periods, from which they recolonized northern areas during interglacial periods (Hewitt 1996, 1999, 2000, 2004; Médail and Diadema 2009). The "northern refugium scenario" (Figure 2) alternatively proposes that species persisted within micro-refugia located between the ice-sheet and the main southern mountain ranges during glacial periods, from where they back-colonized northern areas (Bhagwat and Willis 2008).

In the present review, we focus on the impact of LGM climate change in bryophytes. Bryophytes are non-vascular plants, which means that they cannot pump-up water from the soil, but instead absorb water and nutrients from their entire surface directly from rainfall and atmospheric humidity. Unlike vascular plants, which are drought-resistant and aim at maintaining sufficient levels of water during periods of drought thanks to the presence of a waterproof cuticle and the regulation of gas exchange through their stomata, bryophytes are poïkilohy-

* University of Liège, Institute of Botany, Liège, Belgium. Corresponding author: a.van$\frac{\text { derpoorten@uliege.be. }}{* * \text { Plant Conser }}$

** Plant Conservation and Biogeography Group, Departamento de Botánica, Ecología y Fisiología Vegetal, Facultad de Ciencias, Universidad de La Laguna, La Laguna, Islas Canarias, Spain. 


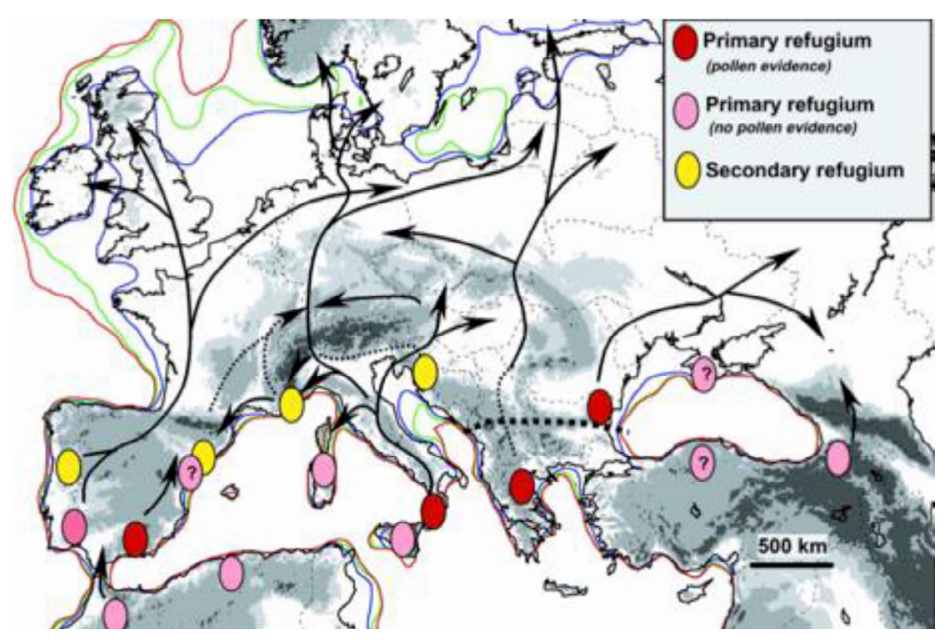

Figure 1. Southern glacial refugia and major post-glaciation migration routes of white oaks in Europe (reproduced from Petit et al. 2002).

dric, i.e., drought-tolerant. This means that they dry-out with ambient air, become dormant under dry conditions and resume physiological activity upon moistening. Bryophytes are therefore very sensitive to variations of the precipitation regime $(\mathrm{He}$ et al. 2016). Furthermore, bryophytes globally exhibit a very high cold tolerance. Recent evidence pointed to their ability of in-vitro regeneration after hundreds to thousands of years in ice (La Farge et al. 2013; Roads et al. 2014), supporting the application of the northern refugium hypothesis in the group. Bryophytes are also very efficient dispersers (see Patiño and Vanderpoorten 2018 for review), and these high long-distance capacities raise the intriguing idea that postglacial recolonization could have taken place from geographically remote areas. In Europe for instance, mounting evidence points to the relevance of Macaronesian islands (Hutsemékers et al. 2011; Laenen et al. 2011) and North America (Stenøien et al. 2011) as sources of recolonizing propagules.

Reconstructing the Quaternary history of European bryophytes has long been a challenging issue because, except for macro-remains preserved in peat, the fossil record is extremely poor as compared to vascular plants (see Patiño and Vanderpoorten 2018 for review), calling for a molecular phylogeographic approach. Although several species-specific studies have been published (see Kyrkjeeide $e t$ al. 2014 for review), there has been to date no comprehensive effort to reconstruct the Quaternary history of bryophytes. Here, we review most recent phylogeographic evidence (Patiño et al. 2015; Ledent et al. 2019) to show that post-glacial recolonization patterns in European bryophytes are unique among previously published work on other groups of plants and animals due to the substantial contribution of allochtonous migrants, with a substantial input of the Macaronesian islands that would, at first sight, not be expected. 


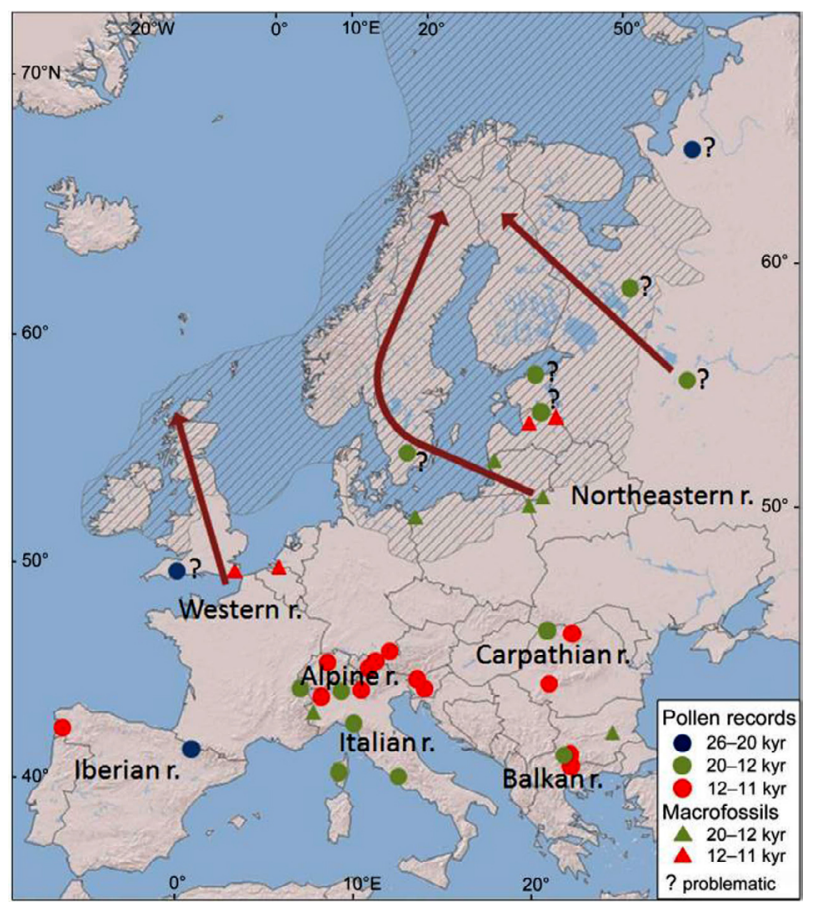

Figure 2. Putative Last Glacial Maximum refugia and directions of postglacial Alnus migration (reproduced from Douda et al. 2014).

\subsection{ReCONSTRUCTING BIOGEOGRAPHIC Histories: AN APPROXIMATE BAYESIAN COMPUTATIONS IN A COALESCENT CONTEXT}

Attempting at reconstructing species historical biogeography from the analysis of molecular data, which is the field of phylogeography (Avise et al. 1987), has long been based on the a posteriori interpretation of summary statistics of genetic structure and diversity and of the topologies of gene trees. Such a descriptive approach does not make it possible to statistically compare competing scenarios to identify the one(s) that best fit to the data, and the level of confidence of the best-fit scenario (Knowles and Maddison 2002). Model-based methods, particularly models that incorporate coalescent theory (Box 1), have therefore been increasingly developed during the last decade (Thomé and Carstens 2016).

In this framework, Patiño et al. (2015) and Ledent et al. (2019) attempted at reconstructing the post-glacial history of 11 and 12 bryophyte species whose distribution range is restricted to the North-East Atlantic region, encompassing the Macaronesian islands and the western fringe of Europe, and encompasses the entire European continent as well as large portions of the Holarctic, respectively. Coalescence simulations were performed in both cases to determine whether the post-gla- 

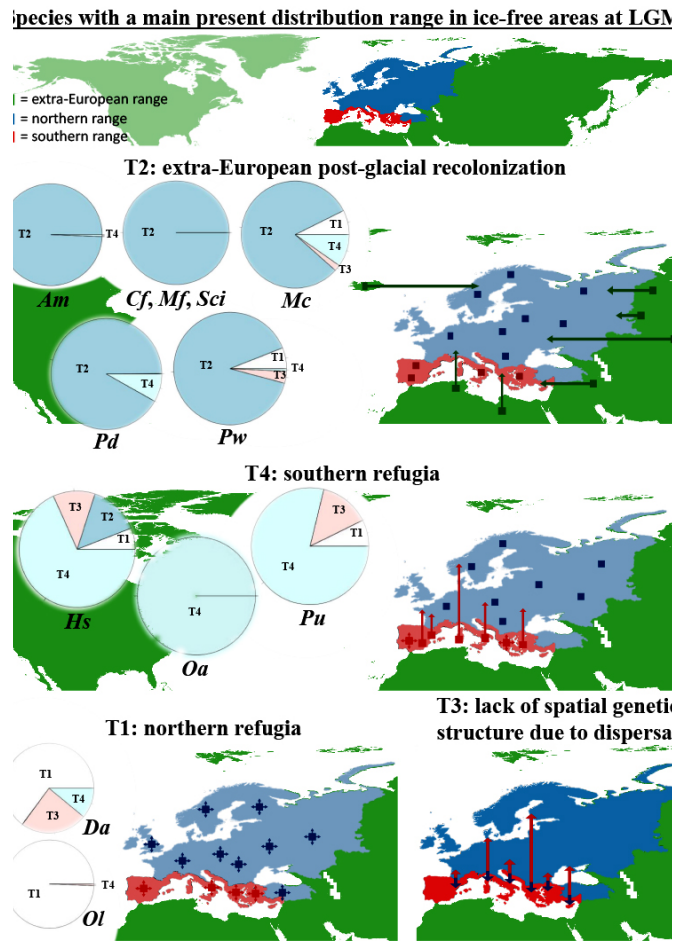

Figure 3. Support for four competing historical scenarios of post-glacial recolonisation of bryophytes in Europe from coalescent simulations (see Box 1). Pie diagrams represent the posterior probabilities of each scenario. T1. northern micro-refugia.

T2. extra-European recolonization. T3. 'panmictic' scenario, according to which high, ongoing migration rates have erased any historical signal in spatial patterns of genetic structure and diversity. T4. southern refugia (reproduced from Ledent et al. 2019).

cial recolonization of Europe took place from (1) local refugia located in the southern (1a) or northern (1b) regions or (2) from allochtonous migrants.

\subsection{Post-glacial origin of the European Bryophyte Flora}

The postglacial assembly of European and NE Atlantic bryophyte species involves a complex history from multiple sources, as different scenarios of postglacial recolonization clearly emerged as the best-fit scenario for different species (Figures 3,4$)$. This complexity contrasts with the prevailing model in which species migrated northwards from southern refugia (Hewitt 2000; Petit et al. 2003). These findings thus challenge the taxonomic generality of the southern refugium scenario that has long been assumed to explain the distribution of genetic varia- 


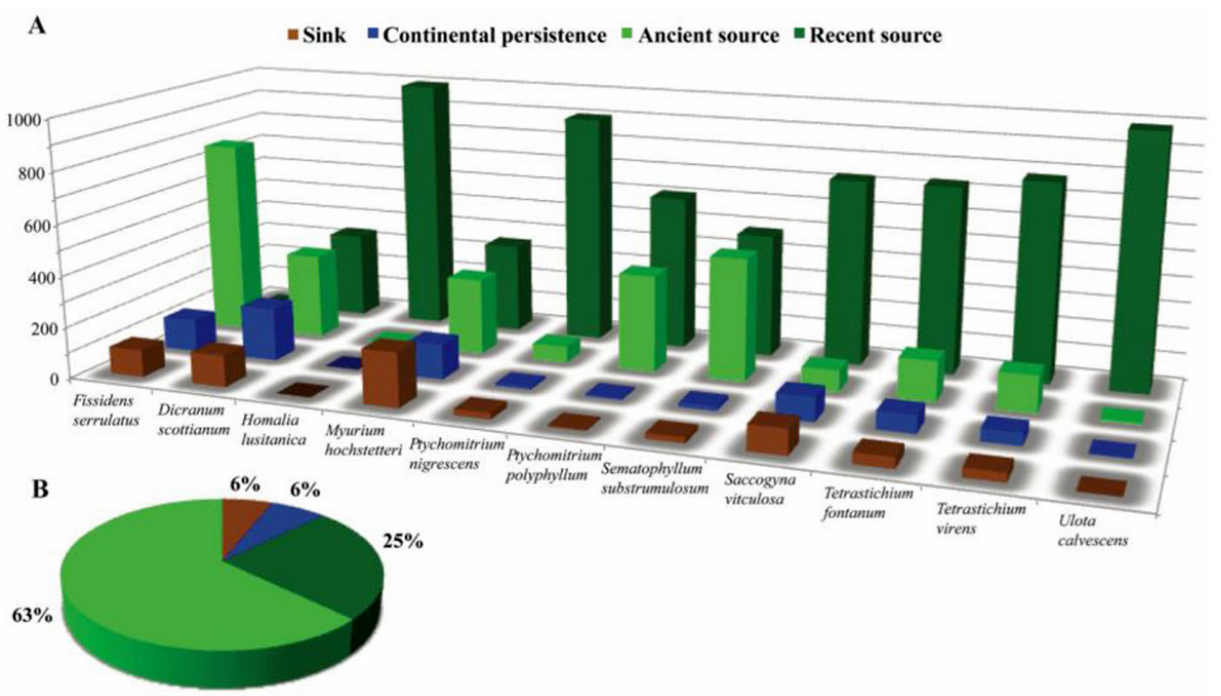

Figure 4. Support for four competing historical scenarios of post-glacial recolonisation of NE Atlantic bryophyte species from coalescent simulations (see Box 1). Bars represent the posterior probabilities of each scenario (A) and the pie diagram (B) represents the average of best-supported simulations for the four competing scenarios across the 11 bryophyte species analyzed. In the 'sink' and 'continental persistence' scenarios, NE Atlantic island populations were historically founded from European migrants, but islands did not contribute to the post-glacial recolonization of Europe in the first case, whereas post-glacial migrations took place between Macaronesia and Europe in the second case. In the 'source' scenario, continental populations were founded de novo by migrants of insular origin. To determine the timing of continental colonization, the source scenario was further split into recent and ancient source scenarios, according to which the founding event of the continental populations took place either between the LGM and the first major ice advance during the Late Pleistocene (recent source) or before (ancient source) (modified from Patińo et al. 2015).

tion in bryophytes based on single-species analyses (Cronberg 2000; Grundmann et al. 2008).

Among the investigated scenarios of post-glacial recolonization, the scenario of extra-European postglacial recolonization clearly emerged as dominant, being the best-fit for 7 out of the 12 species investigated in the European flora and all of the 11 investigated NE Atlantic species (Figures 3, 4). Previous evidence in angiosperms demonstrated the postglacial recolonization of a remote Arctic archipelago from distant sources (Alsos et al. 2007). Individual instances of extra-European refugia (Hutsemékers et al. 2011; Laenen et al. 2011; Stenøien et al. 2011) were further evidenced during the postglacial history of European bryophytes. The substantial contribution of allochthonous migrants in the postglacial assembly of European bryophyte floras is, however, unparalleled in other plants and animals. 

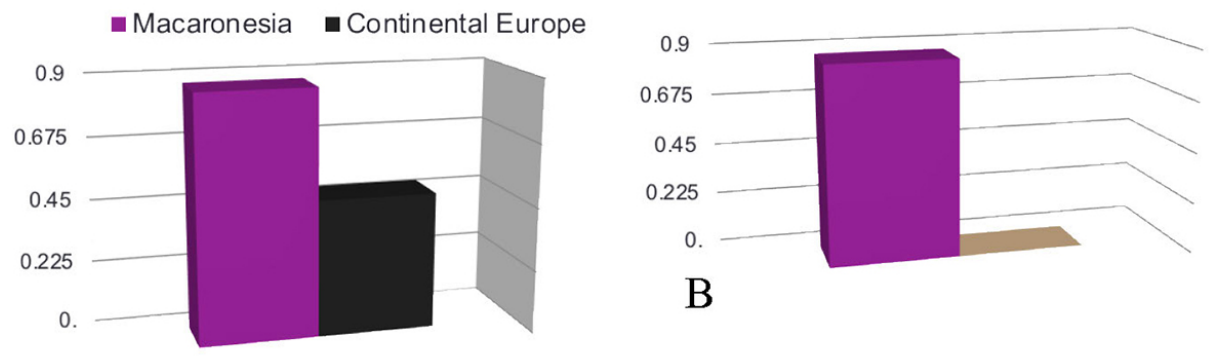

A

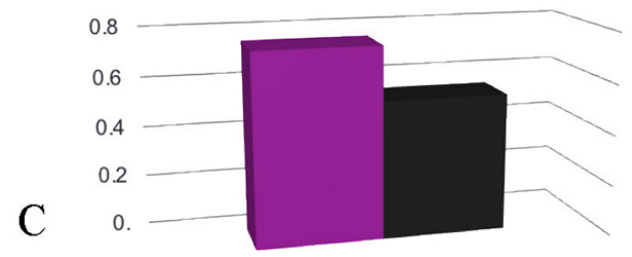

Figure 5. Comparative levels of expected heterozygosity $(\mathrm{He})$ at selected $\mathrm{n}$ and cpDNA loci of three typical NE Atlantic bryophyte species (A. Sematophyllum substrumulosum.

B. Ptychomitrium polyphyllum. C. Saccogyna viticulosa) in Macaronesia and Europe (drawn from data in Patińo et al. 2015).

The substantial difference between the origin of migrants for the European and NE Atlantic floras is that post-glacial recolonization patterns involve the LGM persistence of in-situ small populations of species that pre-existed in Europe before the Ice Age and were reinforced by allochtonous populations for the former, but de novo colonization for the latter. Both floristic (Preston and Hill 1999; Vanderpoorten et al. 2007) and phylogenetic (Devos and Vanderpoorten 2009, Heinrichs et al. 2013) evidence points to a tropical origin for much of the North East Atlantic bryophyte flora. For example, examination of the phylogenetic position of $\mathrm{Myu}$ rium hochstetteri or Tetrastichium spp. from the Moss Tree of Life (Cox et al. 2010) reveals that they are embedded within purely tropical clades. These observations suggest that the Macaronesian archipelagos have played a key role as a stepping-stone for trans-continental migrants before they reach a new continental environment.

Patiño et al. (2015) estimated that the de novo colonization took place, for half of the investigated species, between 28,500 and 41,500 years ago. This extremely recent colonization explains why the strong founding effect associated with the colonization event is still remarkably reflected in the substantially higher genetic diversity observed in the source, island populations than in the sink, continental European populations (Figure 5). Accordingly, genetic diversity in Atlantic bryophytes was substantially higher in island than in continental populations, contributing to mounting evidence that, contrary to theoretical expectations, island plant populations are not necessarily genetically depauperate (García-Verdugo et al. 2015). 


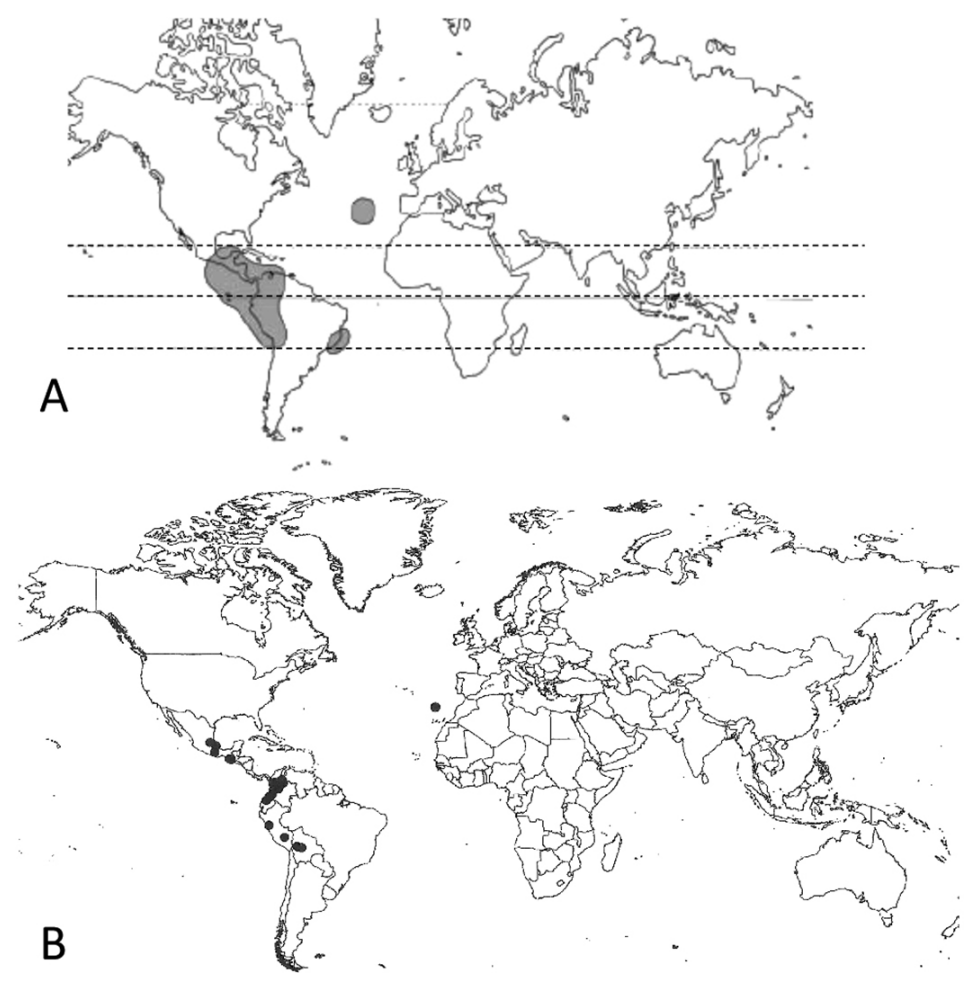

Fig. 6. Disjunct distribution between the Neotropics and Macaronesia. A. Plagiochila sect. glaucescentes (reproduced from Feldberg et al. 2003). B. Syntrichia bogotensis (Gallego et al. 2005).

The very short time frame for the continental colonization events underpins the notion that bryophytes may colonize new suitable habitats as soon as they become available, making them prime indicators of climate change. In this respect, the $5 \%$ of mosses and $8 \%$ of liverworts of the Macaronesian bryophyte flora that are endemic to the islands, as well as the $4 \%$ of mosses and $8 \%$ of liverworts that are disjunct between Macaronesian and tropical areas (Figure 6), appear as candidates for migration towards western Europe and as models for investigating contemporary attempts of continental colonization. Altogether, these observations support growing evidence that oceanic islands are not necessarily the 'end of the colonization road' (Bellemain and Ricklefs 2008). Instead, oceanic islands increasingly appear as additional reservoirs for the assembly of continental floras, in full agreement with ecological predictions, according to which oceanic islands were larger and higher during glacial cycles (Fernández-Palacios et al. 2016; Weigelt et al. 2016), thereby offering ideal conditions for species to persist and diversify before colonizing continental areas. 
One question, however, persists: why would Macaronesian islands represent a mandatory stepping stone for tropical species in transit towards Europe? Our hypothesis is that tropical species need to pre-adapt under sub-tropical to warm temperate conditions in an environment before being able to colonize the temperate European biome. We currently aim at testing this hypothesis by comparing the transcriptome of tropical, Macaronesian and European populations, seeking for genes that appear as candidates for adaptation and investigating differences in the expression of those genes under contrasting climate conditions.

\section{ACKNOWLEDGEMENTS}

AV gratefully thanks the organizers of Floramac 2018 for inviting the present contribution.

\section{AUTHORS' CONTRIBUTION}

Designed the study: A.V. and J.P.

Conducted the analyses: All the authors.

Wrote the manuscript: A.V. with the contribution of A.L. and J.P.

ReCibido: julio de 2019; ACEPTADo: enero de 2020 


\section{REFERENCES}

Alsos, I.G., Eidesen, P.B., Ehrich, D., Skrede, I., Westergaard, K., Jacobsen, G.H., Landvik, J.Y., Taberlet, P and Brochmann, C. 2007. Frequent long-distance plant colonization in the changing Arctic. Science 316: 1606-1609.

Avise, J.C., Arnold, J., Ball, R.M., Bermingham, E., Lamb, T., Neigel, J.E., Reeb, C.A. and SAUNDERS, N.C. 1987. Intraspecific phylogeography: the mitochondrial DNA bridge between population genetics and systematics. Annu. Rev. Ecol. Evol. Syst. 18: 489-522.

Bellemain, E, and Ricklefs, R.E. 2008. Are islands the end of the colonisation road? Trends Ecol. Evol. 23: 461-468.

Bhagwat, S.A. and Willis, K.J. 2008. Species persistence in northerly glacial refugia of Europe: a matter of chance or biogeographical traits? J. Biogeogr. 35: 464-482.

Berger, A., Mesinger, F. and Sijacki, D. 2012. A brief history of the astronomical theories of paleoclimates. In: Berger, A., Mesinger, F. and Sijacki, D. (eds.) Climate Change. Vienna: Springer pp. 107-129.

Clark, P.U., Dyke, A.S., Shakun, J.D., Carlson, A.E., Clark, J., Wohlfarth, B., Mitrovica, J.X., Hostetler, S.W. and Mccabe, A.M. 2009. The Last Glacial Maximum. Science 325: 710-714.

Cox, C.J., Goffinet, B., Wickett, N.J., Boles, S.B. and Shaw, A.J. 2010. Moss diversity: a molecular phylogenetic analysis of genera. Phylotaxa 9: 175-195.

Cronberg, N. 2000. Genotypic diversity of the epiphytic bryophyte Leucodon sciudoides in formerly glaciated versus nonglaciated parts of Europe. Heredity 84: 710-720.

Devos, N. and Vanderpoorten, A. 2009. Range disjunctions, speciation, and morphological transformation rates in the liverwort genus Leptoscyphus. Evolution 63: 779-792.

Douda, J., Doudová, J., Drašnarová, A., Kuneš, P., Hadincová, V., Krak, K., Zákravský, P. and MandÁk, B. 2014. Migration patterns of subgenus Alnus in Europe since the Last Glacial Maximum: A systematic review. PLoS ONE 9: e88709.

Feldberg, K., Lindner, M., Wilson, R., Hartmann, F.A., Schmull, M., Gradstein, S.R. and Heinrichs, J. 2013. Biogeography of Plagiochila (Hepaticae): natural species groups span several floristic kingdoms. J. Biogeogr. 30: 965-978.

Fernández-Palacios, J.M., Rijsdijk, K.F., Norder, S.J., Otto, R., De Nascimento, L., FernánDez-Lugo, S., TJørve, E. and Whittaker, R.J. 2016. Towards a glacial-sensitive model of island biogeography. Global Ecol. Biogeogr. 25: 817-830.

Gallego, M.T., Cano, M.J. and Sérgio, C. 2005. Syntrichia bogotensis (Bryopsida, Pottiaceae) new for Macaronesia. Bryologist 108: 219-223.

García-Verdugo, C., Sajeva, M., La Mantia, T., Harrouni, C., Msanda, F. and Caujapé-CasTELLS, J. 2015. Do island plant populations really have lower genetic variation than mainland populations? Effects of selection and distribution range on genetic diversity estimates. Mol. Ecol. 24: 726-741.

Grundmann. M., Ansell, S.W., Russell, S.J., Koch, M.A. and Vogel, J.C. 2008. Hotspots of diversity in a clonal world -the Mediterranean moss Pleurochaete squarrosa in Central Europe. Mol. Ecol. 17: 825-838. 
He, X., He, K.S. and Hyvönen, J. 2016. Will bryophytes survive in a warming world? Persp. Plant Ecol. Evol. Syst. 19: 49-60.

Hein, J., Schierup, M. and Wiuf, C. 2004. Gene Genealogies, Variation and Evolution: A primer in coalescent theory. Oxford: Oxford University Press $296 \mathrm{pp}$.

Heinrichs, J., Dong, S., Schäfer-Verwimp, A., Pócs, T., Feldberg, K., Czumaj, A., Schmidt, A.R., Reitner, J., Renner, M.A.M., Hentschel, J., Stech, M. and Schneider, H. 2013. Molecular phylogeny of the leafy liverwort Lejeunea (Porellales): Evidence for a neotropical origin, uneven distribution of sexual systems and insufficient taxonomy. PLoS ONE 8: e82547.

Hewitt, G.M. 1996. Some genetic consequences of ice ages, and their role in divergence and speciation. Biol. J. Linn. Soc. 58: 247-276.

Hewitt, G.M. 1999. Post-glacial re-colonization of European biota. Biol. J. Linn. Soc. 68: 87-112.

Hewitt, G.M. 2000. The genetic legacy of the Quaternary ice ages. Nature 405: 907-913.

Hewitt, G.M. 2004. Genetic consequences of climatic oscillations in the Quaternary. Phil. Trans. Roy. Soc. London B 359: 183-195.

Hudson, R.R. 1991. Gene genealogies and the coalescent process. In: Futuyma, D. and Antonovics, J. (eds.), Oxford Surveys in Evolutionary Biology. Oxford: Oxford University Press pp. 1-44.

Hutsemékers, V., Szövényi, P., Shaw, A.J., González-Mancebo, J.M., Muñoz, J. and VanderPOORTEN, A. 2011. Oceanic islands are sources not sinks of biodiversity in spore-producing plants. Proc. Natl. Acad. Sci. USA 108: 18989-18994.

Kingman, J.F.C. 1982. The coalescent. Stoch. Proces. Appl. 13: 235-248.

Knowles, L.L. and Maddison, W.P. 2002. Statistical phylogeography. Mol. Ecol. 11: 2623-2635.

Kyrkjeeide, M.O., Stenøien, H.K., Flatberg, K.I. and Hassel, K. 2014. Glacial refugia and post-glacial colonization patterns in European bryophytes. Lindbergia 2: 47-59.

Laenen, B., Désamoré, A., Devos, N., Shaw, A.J., González-Mancebo, J.M., Carine, M.A. and VAnderpoorten, A. 2011. Macaronesia: a source of hidden genetic diversity for postglacial recolonization of western Europe in the leafy liverwort Radula lindenbergiana. J. Biogeogr. 38: 631-639.

La Farge, C., Williams, K.H. and England, J.H. 2013. Regeneration of Little Ice Age bryophytes emerging from a polar glacier with implications of totipotency in extreme environments. Proc. Natl. Acad. Sci. USA, 110: 9839-9844.

Ledent, A., Désamoré, A., Laenen, B., Mardulyn, P., Mcdaniel, S.F., Zanatta, F., Patiño, J. and Vanderpoorten, A. 2019. No borders during the post-glacial assembly of European bryophytes. Ecol. Lett., 22: 973-986.

Lumibao, C.Y., Hoban, S.M. and Mclachlan, J. 2017. Ice ages leave genetic diversity 'hotspots' in Europe but not in Eastern North America. Ecol. Lett. 20: 1459-1468.

Marjoram, P. and Joyce, P. 2011. Practical Implications of Coalescent Theory. In: Heath, L.S. and Ramakrishnan, N. (eds.), Problem Solving Handbook in Computational Biology and Bioinformatics. Boston, MA: Springer US. pp. 63-80.

Médail, F. and Diadema, K. 2009. Glacial refugia influence plant diversity patterns in the Mediterranean Basin. J. Biogeogr. 36: 1333-1345.

Nordborg, M. 2001. Coalescent Theory. In: Balding, D.J., Bishop, M. and Cannings, C. (eds.), Handbook of Statistical Genetics. John Wiley \& Sons pp. 843-877. 
Patińo, J. and Vanderpoorten, A. 2018. Bryophyte biogeography. Critic. Rev. Plant Sci. 37: 175-209.

Patiño, J., Carine, M., Mardulyn, P., Devos, N., Mateo, R.G., González-Mancebo, J.M., Shaw, A.J. and Vanderpoorten, A. 2015. Approximate Bayesian Computation reveals the crucial role of oceanic islands for the assembly of continental biodiversity. Syst. Biol. 64: 579-589.

Petit, R.J., Brewer, S., Bordacs, S., Burg, K., Cheddadi, R., Coart, E., Cottrell, J., Csaikl, U.M., Van Dam, B., Deans, J.D., Espinel, S., Fineschi, S., Finkeldey, R., Glaz, I., Goicoechea, P.G., Jensen, J.S., Konig, A.O., Lowe, A.J., Madsen, S.F., Matyas, G., Munro, R.C., Popescu, F., Slade, D., Tabbener, H., De Vries, S.G.M., Ziegenhagen, B., De Beaulieu, J.L. and Kremer, A. 2002. Identification of refugia and post-glacial colonisation routes of European white oaks based on chloroplast DNA and fossil pollen evidence. For. Ecol. Manag. 156: 49-74.

Petit, R., Aguinagalde, I., De Beaulieu, J.L., Bittkau, C., Brewer, S., Cheddadi, R., Ennos, R., Fineschi, S., Grivet, D., Lascoux, M., Mohanty, A., Müller-Starck, G., Demesure-Musch, B., Palmé, A., Martín, J.P., Rendell, S. and Vendramin, G.G. 2003. Glacial refugia: hotspots but not melting pots of genetic diversity. Science 300: 1563-1565.

Pillans, B. and Gibbard, P. 2012. The Quaternary Period. In: Gradstein, F.M., Ogg, J.G., Schmitz, M. and Ogg, G. The Geologic Time Scale. Elsevier pp. 979-1010.

Preston, C.D. and Hill, M.O. 1999. The geographical relationships of the British and Irish flora: a comparison of pteridophytes, flowering plants, liverworts and mosses. J. Biogeogr. 26: 629-642.

Roads, E., Longton, R.E. and Convey, P. 2014. Millennial timescale regeneration in a moss from Antarctica. Current Biology 24: R222-R223.

Schneider, R., Schmitt, J., Köhler, P., Joos, F. and Fischer, H. 2013. A reconstruction of atmospheric carbon dioxide and its stable carbon isotopic composition from the penultimate glacial maximum to the last glacial inception. Climate of the Past 9: 2507-2523.

Stenøien, H.K., Shaw, A.J., Shaw, B., Hassel, K. and Gunnarsson. U. 2011. North American origin and recent European establishment of the amphi-Atlantic peat moss Sphagnum angermanicum. Evolution 65: 1181-1194.

Tzedakis, P.C., Emerson, B.C. and Hewitt, G.M. 2013. Cryptic or mystic? Glacial tree refugia in northern Europe. Trends Ecol. Evol. 28: 696-704.

Vanderpoorten, A., Rumsey, F. and Carine, M. 2007. Does Macaronesia exist? Conflicting signal in the bryophyte and pteridophyte floras. Am. J. Bot. 94: 625-639.

WaKeley, J. 2001. The coalescent in an island model of population subdivision with variation among demes. Theor. Pop. Biol. 59: 133-144.

Wakeley, J. 2008. Coalescent Theory: An Introduction. W.H. Freeman \& Company 432 pp.

Weigelt, P., Steinbauer, M.J., Sarmento Cabral, J. and Kreft, H. 2016. Late Quaternary climate change shapes island biodiversity. Nature 532: 99-102.

Wu, H., guiot, J., Brewer, S. and Guo, Z. 2007. Climatic changes in Eurasia and Africa at the last glacial maximum and mid-Holocene: reconstruction from pollen data using inverse vegetation modelling. Clim. Dim. 29: 211-229. 


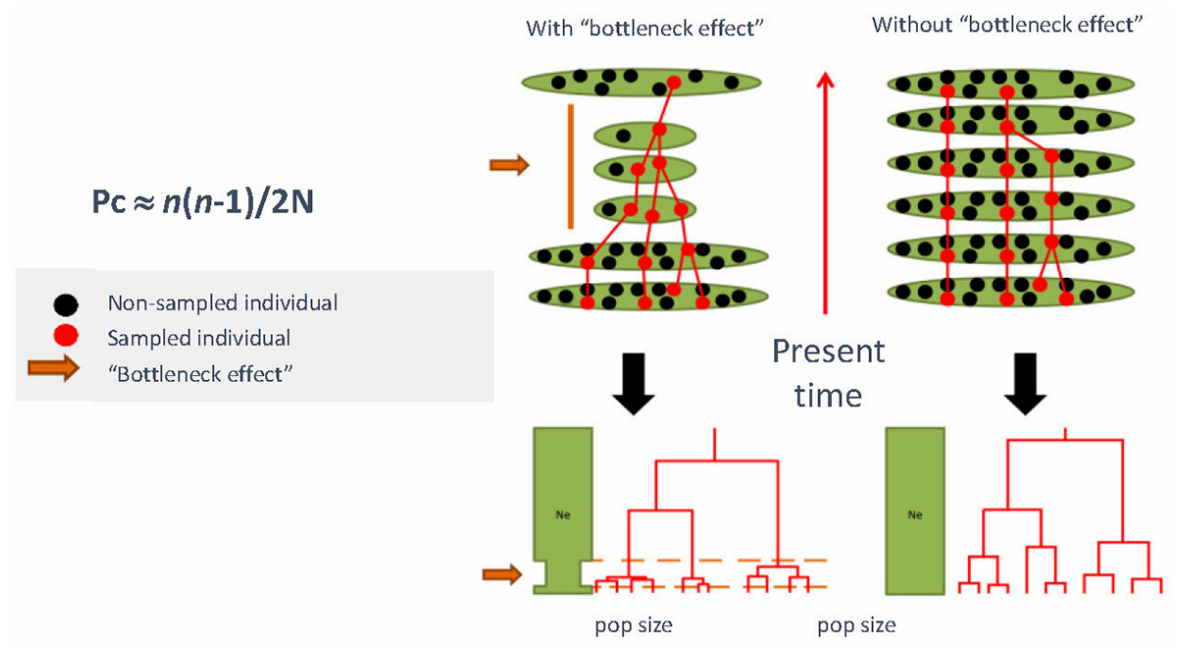

Figure S1. Hypothetical gene genealogies for a standard coalescent model (right) and a bottleneck scenario (left).

\section{BOX 1. IDENTIFYING BEST-FIT HISTORICAL BIOGEOGRAPHIC SCENARIOS FROM COALESCENT SIMULATIONS}

The coalescent model, first described by Kingman (1982), aims at reconstructing the genealogy of all sampled gene copies of a given genetic marker in a population going backward in time until reaching the last common ancestral copy of all of them (see Hein et al. 2004; Marjoram and Joyce 2011; Nordborg 2001; and Wakeley 2008 for review). In a coalescent model, gene genealogies are controlled by demographic events, assuming that all gene copies have the same probability to be transferred to the next generation under a neutral model of molecular evolution in the absence of any selection.

The coalescent model defines the probability of coalescence Pc, which corresponds to the probability that two of the n sampled gene copies (red dots in Figure S1) among the total number of gene copies $(\mathrm{N})$ share a common ancestor at a given generation, and the coalescence time, which corresponds to the number of generations between two coalescence events. Pc can be roughly described as a function of the ratio between $\mathrm{n}$ and $\mathrm{N}$. In a standard coalescent model, $\mathrm{N}$ remains constant through time. Due to the coalescence process, $n$ decreases going back in time, so that Pc progressively decreases, leading to increasing coalescence times represented by increasingly long branches towards the root (Figure S1 right). If the population undergoes a bottleneck back in time (arrow in Figure S1), and $\mathrm{N}$ reaches lower values during the bottleneck, whereas $\mathrm{n}$ is not affected, resulting in an increasing of Pc during that period, shorter coalescence times. A 'bottleneck' coalescent tree is therefore represented by a series of shorter branches during the bottleneck event (Figure S1 left). 
When several populations are involved, the structured coalescent model aims at reconstructing the genealogy of all sampled gene copies across a meta-population divided into subpopulations (Wakeley 2001). If we consider a meta-population subdivided into two subpopulations where at each generation, a small fraction of each subpopulation is made of migrants from the other subpopulation, the probability of coalescence between two sampled gene copies coming from the same subpopulations among all sampled gene copies of the meta-population $(\operatorname{Pc}(\mathrm{s}))$ and the probability of coalescence between two sampled gene copies coming from the two different subpopulations among all sampled gene copies of the meta-population $(\mathrm{Pc}(\mathrm{d}))$ can be established at a given generation. $\operatorname{Pc}(s)$ is the same than the probability of coalescence in a unique panmictic population, while $\mathrm{Pc}(\mathrm{d})$ depends on the migration rate between the two subpopulations and is likely to be much smaller than $\operatorname{Pc}(s)$. The time of coalescence, which corresponds to the time required to reach the common ancestor of two sampled gene copies among all sampled gene copies in a given population, can be established as well for two sampled gene copies coming from the same subpopulation and two sampled gene copies coming from the two different subpopulations. The expectation of those times (Et) follows these two relations:

$$
\operatorname{Et}(\mathrm{s})=\mathrm{n} \text { and } \operatorname{Et}(\mathrm{d})=\mathrm{n}+\frac{(\mathrm{n}-1)}{\mathrm{M}} ;
$$

with $\operatorname{Et}(s)$, the expectation of the time of coalescence between two sampled gene copies coming from the same subpopulation; $\mathrm{Et}(\mathrm{d})$, the expectation of the time of coalescence between two sampled gene copies coming from the two different subpopulations; $\mathrm{n}$, the sampling size of the meta-population; and $\mathrm{M}$, the migration rate between the two subpopulations. Following these equations, if $\mathrm{M}$ is small, $\mathrm{Et}(\mathrm{d})$ is much larger than $\mathrm{Et}(\mathrm{s})$, so that the differentiation between the two subpopulations is high (Figure S2); while if $\mathrm{M}$ is large, $\mathrm{Et}(\mathrm{d})$ is close to $\mathrm{Et}(\mathrm{s})$, so that the two subpopulations are similar (Figure S2) (Hudson 1991). In a meta-population context, the migration rate between subpopulations is thus another important parameter, along with the sampling size and the effective population size of subpopulations, that will impact the gene genealogies of any genetic marker simulated under the coalescent model. Because the demographic parameters $\mathrm{N}$ and $\mathrm{M}$ are unknown, they are sampled from user-defined prior probability distributions to generate millions of coalescence trees for each scenario.

In order to determine the most likely demographic scenario, DNA alignments of identical size as the observed ones are simulated for each scenario. Nucleotide substitution models are employed to predict mutations depending on branch length (Figure S3).

Mutations are thus more likely to occur along long branches. In a 'bottleneck' coalescent simulation, mutations tend to accumulate along the long branches before the bottleneck event. As a result, the majority of these mutations occurs along the deepest branches and are shared among many individuals. In standard coalescent, in contrast, more mutations occur towards the shallowest branches. As a result, and for the same number of mutations, more alleles are expected under a standard coalescent than under a 'bottleneck' coalescent simulation (for example, 5 and 9 
(a)

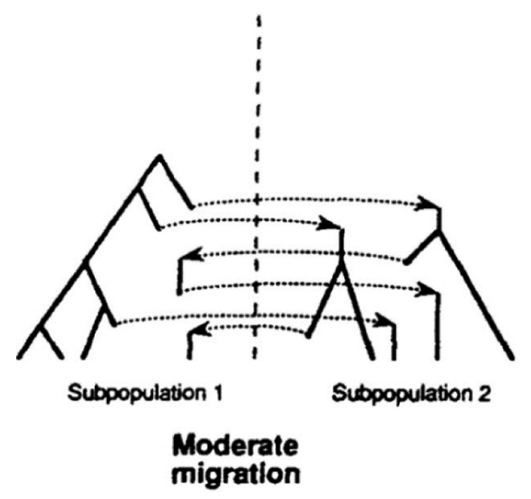

(b)

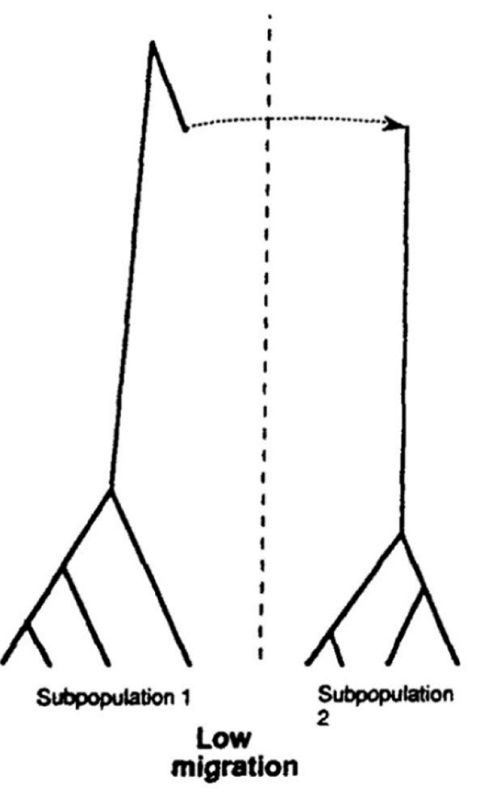

Figure S2: Example of a genealogy for a sampling size of 8, 4 from each of 2 subpopulations, when migration rate is moderately high (a) or involved a single dispersal event (b). Each migration event is indicated by a dotted line with an arrow that indicates the actual direction of movement of an individual migrant (Modified from Hudson 1991).

With "bottleneck effect"

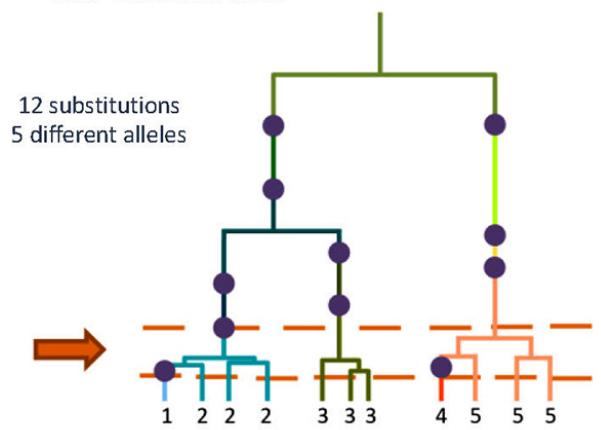

Without "bottleneck effect"

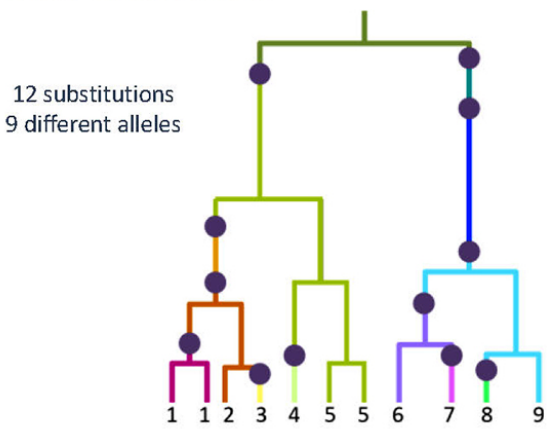

Substitution in one site

"Bottleneck effect"

$1,2, \ldots 9$ Different alleles

Figure S3. Mutation mapping using DNA substitution models on the gene genealogies resulting from coalescent simulations under a standard (right) and bottleneck (left) coalescence process 
alleles for 12 mutations in the bottleneck and standard coalescent trees in Figure S3). This process is repeated along each of the simulated gene genealogies to generate distributions of DNA sequences expected under different historical scenarios. Finally, summary statistics (e.g., number of alleles, Fst...) of these simulated DNA sequences are computed and a distance between the summary statistics of each simulation and of the observed data is computed. The scenario with the highest proportion of shortest distances is identified as the best-fit model. 